OPEN ACCESS

Edited by:

Anwen Shao,

Zhejiang University, China

Reviewed by:

Lingfei Li,

The University of Hong Kong, Hong

Kong SAR, China

Jianming Zhu,

Second Affiliated Hospital of Nanchang University, China

*Correspondence:

Zhuoer Pan

panzhuoerrj@163.com

Specialty section: This article was submitted to

Neuropharmacology, a section of the journal

Frontiers in Pharmacology

Received: 31 January 2022

Accepted: 21 February 2022

Published: 08 March 2022

Citation:

Zhu Y, Sun Y, Hu J and Pan Z (2022) Insight Into the Mechanism of Exercise

Preconditioning in Ischemic Stroke.

Front. Pharmacol. 13:866360.

doi: 10.3389/fphar.2022.866360

\section{Insight Into the Mechanism of Exercise Preconditioning in Ischemic Stroke}

\author{
Yuanhan Zhu ${ }^{1}$, Yulin Sun ${ }^{1}$, Jichao $\mathrm{Hu}^{2}$ and Zhuoer $\mathrm{Pan}^{2 *}$ \\ ${ }^{1}$ Department of Neurosurgery, Zhejiang Rongjun Hospital, Jiaxing, China, ${ }^{2}$ Department of Orthopedics, Zhejiang Rongjun \\ Hospital, Jiaxing, China
}

Exercise preconditioning has attracted extensive attention to induce endogenous neuroprotection and has become the hotspot in neurotherapy. The training exercise is given multiple times before cerebral ischemia, effectively inducing ischemic tolerance and alleviating secondary brain damage post-stroke. Compared with other preconditioning methods, the main advantages of exercise include easy clinical operation and being readily accepted by patients. However, the specific mechanism behind exercise preconditioning to ameliorate brain injury is complex. It involves multi-pathway and multi-target regulation, including regulation of inflammatory response, oxidative stress, apoptosis inhibition, and neurogenesis promotion. The current review summarizes the recent studies on the mechanism of neuroprotection induced by exercise, providing the theoretical basis of applying exercise therapy to prevent and treat ischemic stroke. In addition, we highlight the various limitations and future challenges of translational medicine from fundamental study to clinical application.

Keywords: exercise preconditioning, ischemic stroke, neurprotection, apoptosis, neuroinflammation, oxidative stress

\section{INTRODUCTION}

Stroke is primarily divided into hemorrhagic (intracranial hemorrhage and subarachnoid hemorrhage) and ischemic stroke. Ischemic stroke accounts for up to $80 \%$ of all strokes and is one of the most fatal global diseases with rapid onset, high mortality, and high disability [Amarenco et al., 2009; Hsieh et al., 2010 (accessed on 18 January 2022)]. The treatment principle behind ischemic stroke is to rapidly reconstruct blood reperfusion, restore oxygen supply to the brain, and remove harmful metabolites to reduce the cerebral infarction volume (Bhatia et al., 2010; Diprose et al., 2021). In recent years, neuroprotective agents have been studied based on anti-oxidation, antiapoptosis, inhibition of excitatory amino acid release, anti-inflammation, vascular neuroprotection, and nanoparticles (Subedi and Gaire, 2021a; Chen et al., 2021; Zheng et al., 2021; Kaur and Sharma, 2022). However, most effective drugs in animal experiments often fail in clinical trials (Gladstone et al., 2002; Wahlgren and Ahmed, 2004). Therefore, finding other effective treatments besides drugs has been the emerging idea.

Ischemia tolerance has attracted wide attention as an effective protective strategy for cerebral ischemia. Ischemic preconditioning refers to tissue tolerance during long-term ischemic injury after one or more transient ischemia-reperfusion. It usually manifests as reduced cellular death, decreased cerebral infarct size, and improved organ dysfunction (Liu et al., 2021a; Correia et al., 2021; Ripley et al., 2021). Ischemic preconditioning is an effective neuroprotective method of endogenous cerebral ischemia, with exercise preconditioning being an essential type. Exercise preconditioning can effectively induce ischemia tolerance, exert neuroprotective effects, and alleviate brain damage 
post-stroke by providing training multiple times before ictus. Compared with other preconditioning methods, its advantages are easy to master, operate clinically, and easily accepted by patients (Egan et al., 2014). Moreover, clinical and animal experiments have ascertained the neuroprotective effect of exercise preconditioning Table 1 . The underlying mechanism involves regulating the inflammatory response, inhibiting oxidative stress and apoptosis, promoting neural regeneration, contributing to brain structure and function remodeling, and reducing tissue injury after cerebral ischemia (Sakakima, 2019; Hafez et al., 2020; Hafez et al., 2021).

\section{MECHANISM OF EXERCISE PRECONDITIONING INDUCED CEREBRAL ISCHEMIA TOLERANCE}

\section{Attenuation of Neuronal Apoptosis}

Apoptosis is programmed cell death, having the characteristics of selectivity, initiative, and reversibility. Cellular necrosis is characterized by cell swelling, membrane rupture, and random degradation of DNA. In contrast, cellular apoptosis involves dense chromatin, formation of DNA fragments, cytoplasmic foam, and apoptotic bodies (Park et al., 2021a; Moujalled et al., 2021; Saleem, 2021). Apoptosis is crucial in ischemic injury and is the primary form of delayed neuronal death after cerebral ischemia (Mitsios et al., 2007; Radak et al., 2017; Uzdensky, 2019). Therefore, brain damage will be alleviated if the occurrence and development of neuronal apoptosis are effectively prevented. Primarily, there are three apoptotic pathways: endoplasmic reticulum stress pathway, death receptor pathway, and mitochondrial pathway (Prentice et al., 2015; Redza-Dutordoir and Averill-Bates, 2016; Wei et al., 2018). In addition, many apoptosis-related genes and proteins are regulated and involved in apoptosis after cerebral ischemia (Ferrer et al., 2003; Uzdensky, 2019).

Previous studies have observed that exercise preconditioning can effectively alleviate cerebral ischemia associated tissue damage caused. One study revealed that preconditioned exercise retained more surviving neurons within the hippocampus of the ischemic brain tissue, effectively reducing neuronal death (Tahamtan et al., 2013). Another report depicted that exercise training could effectively induce autophagy and reduce neuronal apoptosis after stroke (Zhang et al., 2013). Exercise can induce the expression of the heat shock protein (HSP)-70, which attenuates apoptosis by inhibiting apoptosisinducing factors and elevating anti-apoptotic proteins expression, such as Bcl-2, leading to the alleviation of cerebral ischemic injury (Zhang et al., 2011). Wang et al. (2019b) observed that preischemic treadmill exercise improves post ischemic brain injury outcomes by preserving both the old and newly formed HSP-72-containing neurons within rats. Similarly, Lin et al. (2015) proposed that preischemic treadmill exercise improves the outcome of ischemic stroke by elevating the numbers of neurons and glial cells containing HSP-20. In addition, several studies explored the potential mechanism underlying exerciseinduced neuroprotection after ischemic stroke. Liebelt et al.
(2010) suggested that exercise preconditioning can reduce neuronal apoptosis and cerebral infarction volume through upregulation of HSP-70 and ERK $1 / 2$. Additionally, ERK and HSP-70 inhibitors could simultaneously eliminate the protective effects of exercise preconditioning on the brain. Other studies found that preischemic treadmill exercise reduced hippocampal microvascular injury after stroke, prevented zonula occludens-1 reduction in the hippocampus, and inhibited matrix metalloproteinase-9 (MMP-9) activation after stroke (Lee et al., 2019). Another team also revealed the changes of MMP-9 in stroke mice, and they observed that exercise preconditioning induced a better outcome than the control ischemic mice, manifested by reduced MMP-9, diminished infarct volume, and significantly improved neurological deficits (Naderi et al., 2018). Exercise preconditioning may inhibit MMP-9 activity by upregulating ERK1/2 expression and reducing neuronal apoptosis level after cerebral ischemia (Chaudhry et al., 2010). ERK-mediated signaling pathways are involved in ischemia-induced apoptosis and regulate $\mathrm{Bax}$ and $\mathrm{Bcl}-2$ protein expression after stroke ( $\mathrm{Li}$ et al., 2021b). The mechanism of exercise preconditioning affecting Bcl-2 and Bax proteins expression is similar to hypoxia preconditioning, among which caspase 3, Bcl-2, and Bax are the core members regulating neuronal apoptosis (Liu et al., 2021d). Choi et al. (2013) observed that short-term running exercises inhibited the division of DNA induced by hypoxicischemic injury. Thus, it effectively reduced the expression of caspase- 3 and inhibited neuronal apoptosis (Choi et al., 2013). Zhang et al. (2019). showed that voluntary wheel running inhibits cellular apoptosis by downregulating the $\mathrm{Bax} / \mathrm{Bcl}-2$ ratio and caspase- 3 protein expression. On further analysis, both mild exercise postconditioning and intense exercise postconditioning significantly decreased brain infarct volumes and apoptosis compared to the resting rats. Moreover, mild exercise postconditioning enhanced $\mathrm{Bcl}-2$ expression and the Bcl-2/Bax ratio (Li et al., 2021a). Controversially, Li et al. (2017b) found that Bcl-2 expression was not affected by exercise after stroke, indicating the importance of the exercise time point. Terashi et al. (2019) investigated the neuroprotective effect of various frequency preconditioning exercises on neuronal apoptosis post cerebral ischemia in rats. They observed that highintensity preconditioning exercise for three or more times per week exert neuroprotective effects by downregulating the Bax/ Bcl-2 ratio and caspase- 3 activation after stroke (Terashi et al., 2019). The above mentioned results indicate that both pre- or postconditioning exercise can potentially induce ischemic tolerance by regulating apoptosis and anti-apoptosis-related proteins. Therefore, exploring the most suitable time points, intensity and frequency of exercise should be incorporated in future studies.

\section{Inhibition of Oxidative Stress}

When the body is subjected to harmful stimulation, the oxidation-antioxidation balance system is broken, leading to oxidative tissue damage through the accumulation of reactive oxygen species (ROS) in cells (Lushchak et al., 2021). ROS mainly includes singlet oxygen, ozone, hydrogen peroxide, and oxygen- 
free radicals. ROS can be produced through aerobic metabolism during normal physiological conditions, and the production and elimination of ROS maintain a dynamic balance in the body. Nitricoxidesynthas, cyclooxygenase, xanthine dehydrogenase/ xanthine oxidase, reduced-type coenzyme II oxygenase, myeloperoxidase, and other enzymes promote ROS production. In contrast, superoxide dismutase, catalase, peroxidase, glutathione peroxidase, and other enzymes inhibit ROS production (Kalyanaraman, 2013; Griffiths et al., 2014; Moldogazieva et al., 2018). Increased oxygen free radical generation and/or decreased scavenging capacity of the antioxidation system in the injured area after cerebral ischemia contributes to ROS (Shao et al., 2020; Duan et al., 2021; Jelinek et al., 2021), leading to neuronal death (Li et al., 2018). Brain tissue is rich in lipids and is highly sensitive to oxidative damage caused by ROS, characterizing oxidative stress as an essential target in treating ischemic stroke (Liu et al., 2002; Liu, 2003; Schönfeld and Reiser, 2017).

Ostuka et al. (2021b) conducted an animal study investigating the role of exercise preconditioning in subarachnoid hemorrhage (SAH). It was found that preconditioning ameliorates early brain injury post SAH. Moreover, the expression of 4-hydroxynonenal and nitrotyrosine was reduced by $\mathrm{Nrf} 2 / \mathrm{HO}-1$ pathway activation, improving the oxidative stress indicators (Otsuka et al., 2021b). Another study from the same team revealed that exercise preconditioning could decrease ROS in focal brain ischemia (Otsuka et al., 2016). Leite et al. (2012) found that swim training could relieve oxidative damage under metabolic stress by inhibiting glutamic acid and promoting the release of nitric oxide. In addition, several animal studies have also established that exercise preconditioning can effectively reduce oxidative damage of brain tissue during cerebral ischemia-reperfusion. Long-term and short-term exercise preconditioning can elevate antioxidant enzyme levels in the hippocampus and cortex, reduce the malondialdehyde content, inhibit oxidative stress, thereby alleviating oxidative damage post cerebral ischemia-reperfusion. This effect was coupled with improved sensory-motor function and memory. Therefore, it suggests that reducing oxidative stress could be an essential mechanism of exercise preconditioninginduced cerebral ischemia tolerance (Radak et al., 2007; Schimidt et al., 2014; Sosa et al., 2015; Chrishtop et al., 2020). The combination therapy of exercise and scalp acupuncture counteracts ischemic brain injury through ROS downregulation, suggesting a potential therapeutic approach in stroke patients (Li et al., 2020b).

Hypoxia inducible factor-1a (HIF-1 $\alpha$ ) is a sensitive oxygen homeostasis regulator and can be rapidly induced by hypoxia/ ischemia. It plays a vital role in ischemic stroke through various mechanisms, including oxidative stress regulation, apoptosis, inflammation, and angiogenesis (Guglielmotto et al., 2009; Miyata et al., 2011; Cheng et al., 2014; Jiang et al., 2020; Peng et al., 2020; Zhang et al., 2021a; He et al., 2021). Previous studies have also determined that HIF-la is crucial in ischemic preconditioning, which reduces brain damage post cerebral ischemia (Liu et al., 2005). HIF-1a exhibits beneficial effects mediated by the Akt signaling pathway and neuroinflammatory response multi-modulation in remote ischemic preconditioning (Yang et al., 2018; Du et al., 2020). In addition, upregulation of HIF-1 $\alpha$ expression by hypoxic preconditioning promotes angiogenesis and neurogenesis. It reduces neuronal death and improves neurological function post ischemic stroke (Chen et al., 2017). Moreover, HIF-1 $\alpha$ is involved in attenuating hyperglycemia-enhanced hemorrhagic transformation through MMP-2 and MMP-9 inhibition poststroke (Soejima et al., 2013). As one of the crucial ways of ischemic preconditioning, exercise-induced neuroprotection is significantly associated with HIF-1a. Exercise preconditioning enhanced HIF-1a expression, contributing to elevated glucose metabolism and ATP production rates after ischemic stroke (Dornbos et al., 2013). Furthermore, exercise preconditioning stimulates the release of HIF-1a. It enhances neurogenesis and angiogenesis (Li et al., 2017a), promoting synaptic plasticity ( $\mathrm{Li}$ et al., 2020a), and reducing neuronal apoptosis (Otsuka et al., 2019). However, exercise preconditioning-induced neuroprotective effect could be quickly lost after exercise cessation. This outcome is a reminder that regulating HIF-1a expression in a time-dependent manner may potentially focus on the further treatment of ischemic stroke (Otsuka et al., 2021a).

\section{Suppression of Inflammation}

An inflammatory response is a pivotal part of the pathological process of ischemic brain injury. The inflammatory response involves a series of inflammatory cells and mediators, which have a dual effect of damage and repair in the occurrence and development of cerebral ischemia. Its effect is correlated with time, scope, and the severity of inflammation (Ceulemans et al., 2010; Wang et al., 2019a; Pluta et al., 2021). Studies have shown that inflammation factor expression in the ischemic region increased significantly within a few hours after cerebral ischemia, with tissue damage caused by various mechanisms, including microvascular occlusion, oxygen free radical generation cytotoxicity enzyme, and chemokine release (Zhang et al., 2021b; Ma et al., 2021).

Glial cells are a significant group of cells in the brain. The number of glial cells is 10-50 times that of neurons and has almost the same total volume as that of neurons. They are mainly categorized into astrocytes, oligodendrocytes, and microglias ( $\mathrm{Xu}$ et al., 2020; Sancho et al., 2021). Microglia secretes inflammatory molecules at the injury site to protect healthy neurons and remove the dead ones. During cerebral ischemia, microglia are rapidly activated, presenting antigens, and releasing inflammatory factors like IL-1 $\beta$, IL-6, and TNF- $\alpha$. In contrast, during the recovery stage of the brain, microglia exhibits an antiinflammatory role (Zhang, 2019; Berchtold et al., 2020; Kang et al., 2020; Subedi and Gaire, 2021b; Hou et al., 2021). Many scholars have explored the impact of microglia during exercise. High-intensity interval training elicited better responses at functional and cardiovascular levels than moderate-intensity continuous training after ischemic stroke. Thus, inflammasome-mediated pyroptosis could be suppressed by the anti-inflammatory effect of exercise due to the shifting of microglial polarization towards the neuroprotective M2 phenotype (Liu et al., 2021b). Moreover, treadmill exercises improved short-term memory, inhibited reactive astrogliosis 


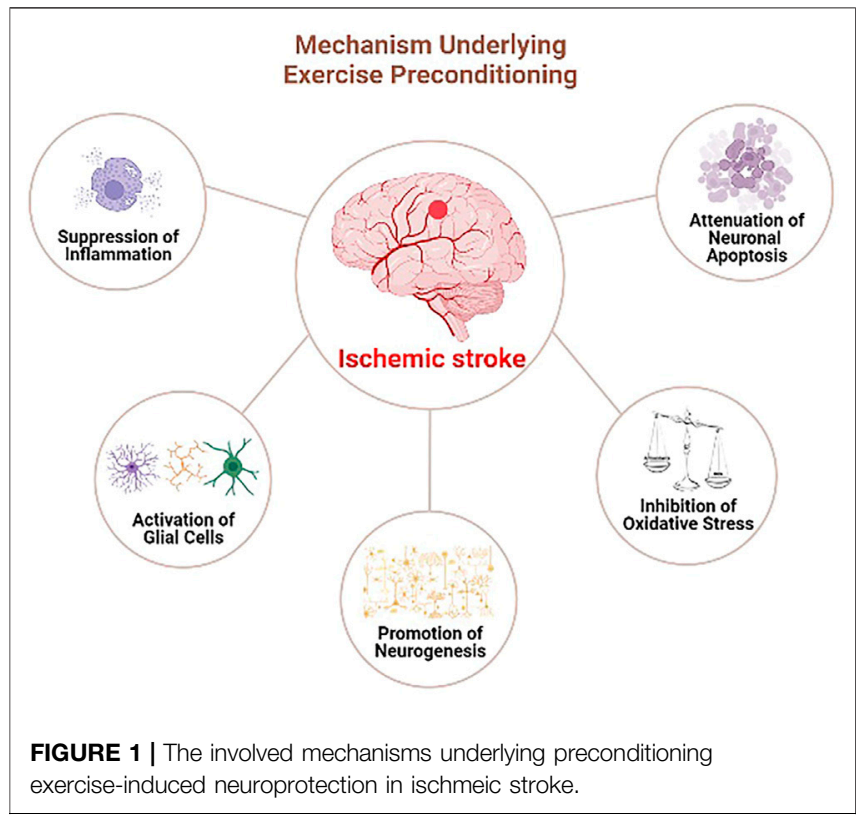

and microglial activation, and suppressed the expression of adhesion molecules and pro-inflammatory cytokines in hyperlipidemic rats (Park et al., 2021b). Casaletto et al. (2022) supported the conclusion that physical activity could be leveraged to reduce pro-inflammatory microglial states in humans through modifiable behavior. They monitored physical activities and cognitive performances in life and quantified the microglial activation and synaptic markers inside brain tissue at death (Casaletto et al., 2022). Treadmill exercise can significantly ameliorate cerebral ischemia-reperfusion injury through IL-4 expression elevation to promote M2 microglia polarization through the JAK1-STAT6 pathway (Lu et al., 2021).

Astrocytes are the most abundant cell type in the central nervous system responding to various disease states. They assist in clearing excessive potassium ions around neurons by regulating the osmotic balance of ions and water and maintaining the relative stability of the neuronal external environment (Jensen et al., 2013; Dinuzzo et al., 2017; Yang et al., 2021b). Astrocytes are also involved in the inflammatory response post cerebral ischemia (Gao et al., 2021; Mi et al., 2021; Kieran et al., 2022), although their roles are different in different stages of inflammation. In the initial phase of inflammation, astrocytes behave as antigen-presenting cells and secrete proinflammatory antigen-presenting cytokines to protect tissues from damage. During the inflammatory response and repair phase peak, astrocytes act as inflammatory regulatory cells, secreting anti-inflammatory cytokines and promoting tissue repair (Regunathan and Piletz, 2003). Jiang et al. (2021) investigated the physical exercise influence on activated astrocytes polarization. They observed that the impact of physical exercise on white matter repair and cognition improvement could be related to astrocytes polarization regulation, inducing myelin debris clearance and efficient remyelination (Jiang et al., 2021). He et al. (2017) revealed that voluntary wheel running accelerated glymphatic clearance, improved the expression and polarization of astrocytic aquaporin 4, attenuated neuroinflammation, and protected mice against synaptic dysfunction and decline in spatial cognition. In addition, Sun et al. (2018) observed that physical exercise released the immune response by decreasing cytokine levels and astrocytes population. Voluntary physical training could modulate the reactive astrocyte state, linked through astrocytic brain-derived neurotrophic factor (BDNF) to improve hippocampal cognition (Belaya et al., 2020).

\section{Promotion of Neurogenesis}

Traditionally, the non-regeneration of neurons is the main reason for the difficulty in neurological functional recovery (Caleo, 2015; Jones, 2017). Recently, researchers have identified that neurons have plasticity and the ability to repair post-injury, which can reshape nerve functions after ischemic stroke. Studies have found that ischemia-induced brain injury can be attenuated by regenerating neurons, synapses, and vessels, improving the defense capability of brain tissue. Moreover, the blood supply to the ischemic area can be restored, thereby promoting remodeling of neural function after ischemic injury (Yang et al., 2021a; Liu et al., 2021c; Zong et al., 2021; Puderbaugh and Emmady, 2022). The improved outcomes indicate that neural regeneration is an essential mechanism behind exercise preconditioning inducing ischemia tolerance (Shamsaei et al., 2015). Praag et al. observed that voluntary exercise ameliorates certain deleterious morphological and behavioral consequences of aging connected with neurogenesis regulation (van Praag et al., 2005). Another study found that treadmill exercise improved short-term and spatial memories by elevating neurogenesis and suppressing apoptosis within the hippocampal dentate gyrus of old-aged rats (Kim et al., 2010). Codd et al. revealed that elevated neurogenesis is sufficient to reverse hippocampal injury-induced deficits in either the damaged or intact hippocampus (Codd et al., 2020). Moreover, the improvement in hippocampal-based learning in aged mice after physical exercise is dependent on neurogenesis in the dentate gyrus and is regulated by growth hormone level changes. Specific changes in hippocampal circuitry underlying the cognitive improvements resulting from physical activity were also identified, suggesting dependency on neurogenesis activation in aged animals (Blackmore et al., 2021; Zhou et al., 2021). Cheng et al. (2020) observed that treadmill exercise promotes neurogenesis and myelin repair by upregulating the $\mathrm{Wnt} / \beta$-catenin signaling pathway and improves the neurological deficit caused by focal cerebral ischemia/ reperfusion. Similarly, Hong et al. (2020) showed that treadmill exercise enhanced motor function and short-term memory by elevating synaptic plasticity and neurogenesis in thrombotic stroke mice. Zhang et al. (2020) indicated that post-stroke exercise improved behavioral function recovery, where synaptogenesis was a beneficial factor.

BDNF plays a vital role in increasing synaptic plasticity and promoting neural regeneration. Xu et al. (2021) found an upregulation of $\mathrm{BDNF}$ and $\operatorname{TrkB}$ in the treadmill exercise group in rats. BDNF/TrkB signaling pathway could modulate the impact of exercise and the enriched environment by improving learning and memory in rats. BDNF expression 
TABLE 1 | Summary of pre-clinical studies of exercise preconditioning in ischemic stroke.

\begin{tabular}{|c|c|c|c|c|c|}
\hline $\begin{array}{l}\text { Exercise } \\
\text { type }\end{array}$ & Exercise manner & $\begin{array}{l}\text { Species and } \\
\text { model }\end{array}$ & Outcome & Involved signal & References \\
\hline $\begin{array}{l}\text { treadmill } \\
\text { exercise }\end{array}$ & $\begin{array}{l}10 \mathrm{~min} / \text { day }(15-25 \mathrm{~m} / \mathrm{min}) \\
5 \text { days/week for } 3 \text { weeks }\end{array}$ & $\begin{array}{l}\text { male Sprague-Dawley } \\
\text { rats, } 60 \text { min of MCAO }\end{array}$ & $\begin{array}{l}\text { reduced infarct volume and } \\
\text { ameliorated sensorimotor function }\end{array}$ & $\begin{array}{l}\text { upregulate BDNF, HIF-1 } 1 \alpha \text {, and } \\
\text { P2X7 receptor }\end{array}$ & $\begin{array}{l}\text { Otsuka et al. } \\
\text { (2021a) }\end{array}$ \\
\hline $\begin{array}{l}\text { treadmill } \\
\text { exercise or } \\
\text { swimming }\end{array}$ & $\begin{array}{l}\text { Swim or run ( } 15 \mathrm{~m} / \mathrm{min}) \\
30 \mathrm{~min} / \text { day, } 5 \text { days/week for } \\
3 \text { weeks }\end{array}$ & $\begin{array}{l}\text { male Wistar rats, } 30 \mathrm{~min} \\
\text { of } \mathrm{MCAO}\end{array}$ & $\begin{array}{l}\text { Increase brain trophic support and } \\
\text { reduce brain damage }\end{array}$ & $\begin{array}{l}\text { Increase the gene expressions of } \\
\text { TrkB, TNF- } \alpha \text {, and MMP2 }\end{array}$ & $\begin{array}{l}\text { Teymuri } \\
\text { Kheravi et al. } \\
(2021)\end{array}$ \\
\hline $\begin{array}{l}\text { treadmill } \\
\text { exercise }\end{array}$ & $\begin{array}{l}4 \text { weeks, the distance of } \\
\text { exercise per week is about } \\
5,000 \mathrm{~m}\end{array}$ & $\begin{array}{l}\text { male Sprague-Dawley } \\
\text { rats, } 90 \text { min of MCAO }\end{array}$ & improve neurocognitive function & Increase the basal dopamine level & Fan et al. (2021) \\
\hline $\begin{array}{l}\text { treadmill } \\
\text { exercise }\end{array}$ & $\begin{array}{l}25 \mathrm{~min} / \text { day for } 4 \text { days, break } \\
\text { for } 2 \text { days, and one acute bout } \\
\text { for } 30 \mathrm{~min}\end{array}$ & $\begin{array}{l}\text { male Wistar rats, embolic } \\
\text { stroke model }\end{array}$ & $\begin{array}{l}\text { reduce the neurovascular injury } \\
\text { and improved functional outcomes }\end{array}$ & $\begin{array}{l}\text { Increase the expression of peNOS } \\
\text { and pAMPK }\end{array}$ & $\begin{array}{l}\text { Hafez et al. } \\
(2020)\end{array}$ \\
\hline $\begin{array}{l}\text { treadmill } \\
\text { exercise }\end{array}$ & $\begin{array}{l}30 \mathrm{~min} / \text { day }(2 \mathrm{~m} / \mathrm{min} \text { for the } \\
\text { first } 5 \mathrm{~min}, 3 \mathrm{~m} / \mathrm{min} \text { for the next } \\
5 \mathrm{~min}, 5 \mathrm{~m} / \mathrm{min} \text { for the last } \\
20 \mathrm{~min}) \text { for } 4 \text { weeks }\end{array}$ & $\begin{array}{l}\text { male Wistar rats, bilateral } \\
\text { common carotid arteries } \\
\text { occlusion }\end{array}$ & $\begin{array}{l}\text { ameliorate shot-term memory } \\
\text { impairment and prevent } \\
\text { microvascular injury in the } \\
\text { hippocampus }\end{array}$ & $\begin{array}{l}\text { prevente the reduction of } \mathrm{ZO}-1 \text { in } \\
\text { the hippocampus and inhibite the } \\
\text { activation of MMP-9 }\end{array}$ & Lee et al. (2019) \\
\hline $\begin{array}{l}\text { treadmill } \\
\text { exercise }\end{array}$ & $\begin{array}{l}30 \mathrm{~min}(20 \mathrm{~m} / \mathrm{min}), 30 \mathrm{~min} \\
(30 \mathrm{~m} / \mathrm{min}) \text { and } 60 \mathrm{~min}(30 \mathrm{~m} / \\
\text { min) for } 1 \text { week each }\end{array}$ & $\begin{array}{l}\text { male Sprague-Dawley } \\
\text { rats, MCAO }\end{array}$ & attenuate neurological injury & $\begin{array}{l}\text { preserve old and newly formed } \\
\text { HSP72-containing neurons }\end{array}$ & $\begin{array}{l}\text { Wang et al. } \\
\text { (2019b) }\end{array}$ \\
\hline $\begin{array}{l}\text { treadmill } \\
\text { exercise }\end{array}$ & $\begin{array}{l}30 \mathrm{~min} / \text { day }(25 \mathrm{~m} / \mathrm{min}) \text { for } 3 \text { or } \\
5 \text { days/week for } 3 \text { weeks }\end{array}$ & $\begin{array}{l}\text { male Sprague-Dawley } \\
\text { rats, } 60 \text { min of MCAO }\end{array}$ & $\begin{array}{l}\text { reduce infarct volumes, improve } \\
\text { neurological scores and } \\
\text { sensorimotor function }\end{array}$ & $\begin{array}{l}\text { reduce the } \mathrm{Bax} / \mathrm{Bcl}-2 \text { ratio and } \\
\text { caspase- } 3 \text { activation }\end{array}$ & $\begin{array}{l}\text { Terashi et al. } \\
\text { (2019) }\end{array}$ \\
\hline $\begin{array}{l}\text { treadmill } \\
\text { exercise }\end{array}$ & $\begin{array}{l}30 \mathrm{~min} / \text { day }(25 \mathrm{~m} / \mathrm{min}) \text { for } \\
5 \text { days/week for } 3 \text { weeks }\end{array}$ & $\begin{array}{l}\text { male Sprague-Dawley } \\
\text { rats, } 60 \text { min of MCAO }\end{array}$ & $\begin{array}{l}\text { reduce ischemic neuronal cell } \\
\text { death, induce neuron- and } \\
\text { astrocyte-mediated brain ischemic } \\
\text { tolerance }\end{array}$ & $\begin{array}{l}\text { Increase expression of HIF-1 } \alpha \text {, and } \\
\text { inhibit } 14-3-3 \gamma / p-\beta \text {-catenin } \\
\text { Ser37 anti-apoptotic pathway }\end{array}$ & $\begin{array}{l}\text { Otsuka et al. } \\
(2019)\end{array}$ \\
\hline $\begin{array}{l}\text { treadmill } \\
\text { exercise }\end{array}$ & $\begin{array}{l}30 \mathrm{~min} / \text { day for } 5 \text { days/week } \\
\text { for } 8 \text { weeks }\end{array}$ & $\begin{array}{l}\text { male Wistar rats, } 60 \text { min } \\
\text { of } \mathrm{MCAO}\end{array}$ & $\begin{array}{l}\text { improve neurological function and } \\
\text { BBB integrity }\end{array}$ & $\begin{array}{l}\text { develop higher levels of cortical } \\
\text { VEGF-A and striatal VEGF-R2 }\end{array}$ & $\begin{array}{l}\text { Rezaei et al. } \\
(2018)\end{array}$ \\
\hline $\begin{array}{l}\text { treadmill } \\
\text { exercise }\end{array}$ & $\begin{array}{l}40 \mathrm{~min} / \text { day }(18 \mathrm{~m} / \mathrm{min}) \text { for } \\
5 \text { days/week for } 4 \text { weeks }\end{array}$ & $\begin{array}{l}\text { ovariectomized mice, } \\
\text { permanent MCAO }\end{array}$ & $\begin{array}{l}\text { diminish infarct volume, and } \\
\text { improve neurological deficits }\end{array}$ & $\begin{array}{l}\text { Decrease MMP-9, and increase } \\
\mathrm{IL}-10\end{array}$ & $\begin{array}{l}\text { Naderi et al. } \\
\text { (2018) }\end{array}$ \\
\hline $\begin{array}{l}\text { treadmill } \\
\text { exercise }\end{array}$ & $\begin{array}{l}5 \text { days/week for } 4 \text { weeks, time } \\
\text { and intensity increase } \\
\text { progressively }\end{array}$ & $\begin{array}{l}\text { male wistar rats, } 60 \text { min of } \\
\text { MCAO }\end{array}$ & $\begin{array}{l}\text { reduce brain edema and decrease } \\
\text { the neurological movement } \\
\text { disorders }\end{array}$ & none & $\begin{array}{l}\text { Shamsaei et al. } \\
\text { (2015) }\end{array}$ \\
\hline $\begin{array}{l}\text { treadmill } \\
\text { exercise }\end{array}$ & $\begin{array}{l}30 \mathrm{~min} / \text { day }(15 \mathrm{~m} / \mathrm{min}) \text { for } \\
3 \text { days/week for } 4.5 \text { weeks }\end{array}$ & $\begin{array}{l}\text { male } \mathrm{C} 57 \mathrm{Bl} / 6 \text { mice, } \\
13 \text { min of global cerebral } \\
\text { ischemia }\end{array}$ & $\begin{array}{l}\text { forced treadmill exercise induce a } \\
\text { stress response, and lead to } \\
\text { increased neuronal damage }\end{array}$ & $\begin{array}{l}\text { Increase levels of NLRP3, galectin- } \\
3, \mathrm{IFN} \gamma \text { and IL-10 }\end{array}$ & $\begin{array}{l}\text { Svensson et al. } \\
(2016)\end{array}$ \\
\hline $\begin{array}{l}\text { treadmill } \\
\text { exercise }\end{array}$ & $\begin{array}{l}30 \mathrm{~min} / \text { day }(20 \mathrm{~m} / \mathrm{min}) \text { for } \\
6 \text { days/week }\end{array}$ & $\begin{array}{l}\text { male Sprague Dawley } \\
\text { rats, } 90 \text { min of MCAO }\end{array}$ & $\begin{array}{l}\text { reduce brain infarct volume and } \\
\text { neurological deficits }\end{array}$ & $\begin{array}{l}\text { Increase SOD activity and } \\
\text { decrease the concentration } \\
\text { of MDA }\end{array}$ & $\begin{array}{l}\text { Feng et al. } \\
(2014)\end{array}$ \\
\hline $\begin{array}{l}\text { treadmill } \\
\text { exercise }\end{array}$ & $\begin{array}{l}30 \mathrm{~min} / \text { day }(15 \mathrm{~m} / \mathrm{min}) \text { for } \\
6 \text { days/week for } 3 \text { weeks }\end{array}$ & $\begin{array}{l}\text { male Sprague Dawley } \\
\text { rats, } 120 \text { min of MCAO }\end{array}$ & $\begin{array}{l}\text { improve neurological deficits, } \\
\text { reduce infarct volume, mitigate } \\
\text { pathological damage in the } \\
\text { ischemic cortex }\end{array}$ & $\begin{array}{l}\text { regulation of the TLR } 4 / N F-\kappa B \\
\text { signaling pathway and the } \\
\text { inhibition of central and peripheral } \\
\text { inflammatory cascades }\end{array}$ & Zhu et al. (2016) \\
\hline $\begin{array}{l}\text { treadmill } \\
\text { exercise }\end{array}$ & $\begin{array}{l}30 \mathrm{~min} / \text { day }(25 \mathrm{~m} / \mathrm{min}) \text { for } \\
5 \text { days/week for } 3 \text { weeks }\end{array}$ & $\begin{array}{l}\text { male Sprague Dawley } \\
\text { rats, } 60 \text { min of MCAO }\end{array}$ & $\begin{array}{l}\text { reduce neuronal apoptosis, } \\
\text { oxidative stress, and infract } \\
\text { volume, ameliorate motor function, } \\
\text { increase astrocyte proliferation and } \\
\text { angiogenesis }\end{array}$ & $\begin{array}{l}\text { enhance expression of MK and } \\
\text { BDNF }\end{array}$ & $\begin{array}{l}\text { Otsuka et al. } \\
(2016)\end{array}$ \\
\hline $\begin{array}{l}\text { treadmill } \\
\text { exercise }\end{array}$ & $\begin{array}{l}30 \mathrm{~min}(20 \mathrm{~m} / \mathrm{min}), 30 \mathrm{~min} \\
(30 \mathrm{~m} / \mathrm{min}) \text { and } 60 \mathrm{~min}(30 \mathrm{~m} / \\
\text { min) for } 1 \text { week each }\end{array}$ & $\begin{array}{l}\text { male Sprague Dawley } \\
\text { rats, } 90 \text { min of MCAO }\end{array}$ & $\begin{array}{l}\text { attenuate brain infarct, glial } \\
\text { apoptosis, and neurological } \\
\text { deficits }\end{array}$ & $\begin{array}{l}\text { Increase the numbers of both the } \\
\text { HSP20-containing neurons and } \\
\text { the HSP20-containing glia }\end{array}$ & Lin et al. (2015) \\
\hline swimming & $\begin{array}{l}60 \mathrm{~min} / \text { day for } 6 \text { days/week } \\
\text { for } 4 \text { weeks }\end{array}$ & $\begin{array}{l}\text { Sprague Dawley rats, } \\
120 \text { min of MCAO }\end{array}$ & reduce infarct volume & $\begin{array}{l}\text { upregulate the expression of } \\
\mathrm{HIF-1a}\end{array}$ & $\begin{array}{l}\text { Wang et al. } \\
(2015)\end{array}$ \\
\hline $\begin{array}{l}\text { treadmill } \\
\text { exercise }\end{array}$ & $\begin{array}{l}30 \mathrm{~min} / \text { day }(20 \mathrm{~m} / \mathrm{min}) \text { for } \\
6 \text { days/week for } 3 \text { weeks }\end{array}$ & $\begin{array}{l}\text { male Sprague Dawley } \\
\text { rats, } 120 \text { min of MCAO }\end{array}$ & & 2. & $\begin{array}{l}\text { Wang et al. } \\
\text { (2014) } \\
\text { following page) }\end{array}$ \\
\hline
\end{tabular}


TABLE 1 | (Continued) Summary of pre-clinical studies of exercise preconditioning in ischemic stroke.

\begin{tabular}{|c|c|c|c|c|c|}
\hline $\begin{array}{l}\text { Exercise } \\
\text { type }\end{array}$ & Exercise manner & $\begin{array}{l}\text { Species and } \\
\text { model }\end{array}$ & Outcome & Involved signal & References \\
\hline & & & $\begin{array}{l}\text { reduce brain infarct volume, } \\
\text { cerebral edema and neurological } \\
\text { deficits }\end{array}$ & $\begin{array}{l}\text { regulation of PKC-a-GLT-1- } \\
\text { Glutamate and PI3K/AKt-GLT-1- } \\
\text { Glutamate signal pathway }\end{array}$ & \\
\hline $\begin{array}{l}\text { treadmill } \\
\text { exercise }\end{array}$ & $\begin{array}{l}30 \mathrm{~min} / \text { day }(20 \mathrm{~m} / \mathrm{min}) \text { for } \\
5 \text { days/week for } 2 \text { weeks }\end{array}$ & $\begin{array}{l}\text { male Sprague Dawley } \\
\text { rats, } 120 \text { min of MCAO }\end{array}$ & $\begin{array}{l}\text { improve CBF and neurologic } \\
\text { deficits, reduce infarct volume }\end{array}$ & Decrease ET-1 expression & $\begin{array}{l}\text { Zhang et al. } \\
(2013)\end{array}$ \\
\hline $\begin{array}{l}\text { treadmill } \\
\text { exercise }\end{array}$ & $\begin{array}{l}30 \mathrm{~min} / \text { day }(18 \mathrm{~m} / \mathrm{min}) \text { for } \\
5 \text { days/week for } 3 \text { weeks }\end{array}$ & $\begin{array}{l}\text { male wistar rats, } 10 \text { min of } \\
\text { 4-vessel occlusion model }\end{array}$ & $\begin{array}{l}\text { improve behavioral functions and } \\
\text { maintain more viable cells in the } \\
\text { dorsal hippocampus }\end{array}$ & none & $\begin{array}{l}\text { Tahamtan et al. } \\
\text { (2013) }\end{array}$ \\
\hline $\begin{array}{l}\text { treadmill } \\
\text { exercise }\end{array}$ & $\begin{array}{l}30 \mathrm{~min} / \text { day }(30 \mathrm{~m} / \mathrm{min}) \text { for } \\
5 \text { days/week for } 3 \text { weeks }\end{array}$ & $\begin{array}{l}\text { male Sprague Dawley } \\
\text { rats, } 120 \text { min of MCAO }\end{array}$ & $\begin{array}{l}\text { reduce neurological deficit and } \\
\text { infarct volume, increase the rates of } \\
\text { glucose metabolism }\end{array}$ & $\begin{array}{l}\text { reduce ADP/ATP ratio, increase } \\
\text { GLUT1, GLUT3, and PFK }\end{array}$ & $\begin{array}{l}\text { Dornbos et al. } \\
\text { (2013) }\end{array}$ \\
\hline $\begin{array}{l}\text { treadmill } \\
\text { exercise }\end{array}$ & $\begin{array}{l}30 \mathrm{~min} / \text { day }(30 \mathrm{~m} / \mathrm{min}) \text { for } \\
5 \text { days/week for } 3 \text { weeks }\end{array}$ & $\begin{array}{l}\text { Sprague Dawley rats, } \\
\text { MCAO }\end{array}$ & reduce neuronal apoptosis & $\begin{array}{l}\text { inhibit the expression of MMP-9 } \\
\text { and ERK1/2 expression }\end{array}$ & $\begin{array}{l}\text { Chaudhry et al. } \\
\text { (2010) }\end{array}$ \\
\hline $\begin{array}{l}\text { treadmill } \\
\text { exercise }\end{array}$ & $\begin{array}{l}30 \mathrm{~min} / \text { day }(30 \mathrm{~m} / \mathrm{min}) \text { for } \\
5 \text { days/week for } 3 \text { weeks }\end{array}$ & $\begin{array}{l}\text { Sprague Dawley rats, } \\
\text { MCAO }\end{array}$ & $\begin{array}{l}\text { diminish neuronal injury, reduce } \\
\text { infarct volume }\end{array}$ & $\begin{array}{l}\text { upregulate HSP-70, ERK } 1 / 2 \text { and } \\
\text { Bcl-x(L), downregulate Bax and AIF }\end{array}$ & $\begin{array}{l}\text { Liebelt et al. } \\
\text { (2010) }\end{array}$ \\
\hline $\begin{array}{l}\text { treadmill } \\
\text { exercise }\end{array}$ & $\begin{array}{l}30 \mathrm{~min} / \text { day }(30 \mathrm{~m} / \mathrm{min}) \text { for } \\
5 \text { days/week for } 3 \text { weeks }\end{array}$ & $\begin{array}{l}\text { male Sprague Dawley } \\
\text { rats, } 120 \text { min of MCAO }\end{array}$ & $\begin{array}{l}\text { Decrease neurological deficits, } \\
\text { infarct volume and leukocyte } \\
\text { infiltration }\end{array}$ & $\begin{array}{l}\text { Reduce TNF- } \alpha \text {, ERK 1/2, MMP-9 } \\
\text { and ICDM-1 expression }\end{array}$ & $\begin{array}{l}\text { Curry et al. } \\
\text { (2010) }\end{array}$ \\
\hline
\end{tabular}

BBB, blood-brain barrier; BDNF, brain-derived neurotrophic factor; $C B F$, cerebral blood flow; ERK1/2, extracellular signal-regulated kinase one and 2; GLT-1, glutamate transporter-1; HIF-1 $\alpha$, hypoxia-inducible factor-1 $\alpha$; HSP, heat shock protein; ICDM-1, intercellular adhesion molecule-1; MCAO, middle cerebral artery occlusion; MDA, malondialdehyde; MK, midkine; $M M P$, matrix metalloproteinase-9; NF- $\kappa B$, nuclear transcription factor- $\kappa B$; NLRP3, nucleotide-binding oligomerization domain-like receptor containing pyrin domain 3; peNOS, phosphorylated endothelial nitric oxide synthase; SOD, superoxide dismutase; TLR4, toll-like receptor-4; TNF- $\alpha$, tumour necrosis factor- $\alpha$; TrkB, tropomyosin receptor kinase B; VEGF-A, vascular endothelial $g$ PKC- $\alpha$, protein kinase $C$ - $\alpha$; rowth factor A; VEGF-R2, vascular endothelial growth factor receptor 2; ZO-1, zonula occludens-1.

levels in the ischemic brain were significantly upregulated post exercise cessation in an animal study (Wang et al., 2020), consistent with another study (Xu et al., 2021). Interestingly, a meta-analysis summarized the effects of physical exercise with different intensities, duration, and frequency on peripheral BDNF levels among the sedentary elderly without any cognitive impairment. The results showed that physical exercise did not cause any significant difference in peripheral BDNF concentration (Fleitas et al., 2022), which indicates that BDNF expression in the brain and peripheral plasma are influenced differentially by exercises.

\section{PROSPECTS}

Therefore, exercise preconditioning could induce ischemia tolerance by inhibiting neural apoptosis and oxidative stress, regulating the inflammatory response, promoting neural regeneration, and exerting preventive and protective effects on the ischemic brain injury (Figure 1). Exercise preconditioning depicts a significant application prospect being a safe and slight side-effect strategy to prevent cerebral ischemia. Further studies on the neuroprotective mechanism of exercise preconditioning will identify new therapeutic targets for ischemic stroke. Moreover, supporting exercise training could provide a solid theoretical foundation as effective prevention and control measures of ischemic stroke patients.

However, many problems regarding exercise preconditioning require attention. First, the heterogeneity of population subgroups, including age, gender, dietary habits, etc., should be considered. Different hypoxic degrees, duration, and intensity will induce different effects. For example, how does exercise play a neuroprotective role in inducing cerebral ischemia tolerance among the elderly population with the most incidence of ischemic stroke? What type of exercise, frequency, intensity, and duration could harness the best results? Second, there is a lack of specific indicators to analyze the effect of exercise preconditioning. Applying mild stress may exacerbate the disease state rather than provide a cure in some disease cases. This outcome necessitates understanding the preconditioning and ischemic stroke mechanisms and the stress response of cells/tissues/organs at different stages of ischemic stroke. Moreover, it also requires searching for specific physiological biomarkers to improve the monitoring of disease progression or treatment effectiveness. In addition, the exercise preconditioning mechanism needs to be further explored. Does exercise directly affect the brain or protect brain function through peripheral effect? Which group of brain cells is more sensitive to exercise stimulation? Finally, combining exercise preconditioning with traditional medicine, nanomedicine, or other preconditioning methods needs to be studied, which could be a potential therapeutic approach for ischemic stroke.

\section{AUTHOR CONTRIBUTIONS}

YZ, YS and JH designed and drafted the manuscript. ZP revised the manuscript. All the authors finalized the paper and provided suggestions to improve it. 


\section{REFERENCES}

Amarenco, P., Bogousslavsky, J., Caplan, L. R., Donnan, G. A., and Hennerici, M. G. (2009). Classification of Stroke Subtypes. Cerebrovasc. Dis. 27, 493-501. doi:10.1159/000210432

Belaya, I., Ivanova, M., Sorvari, A., Ilicic, M., Loppi, S., Koivisto, H., et al. (2020). Astrocyte Remodeling in the Beneficial Effects of Long-Term Voluntary Exercise in Alzheimer's Disease. J. Neuroinflammation 17, 271. doi:10.1186/ s12974-020-01935-w

Berchtold, D., Priller, J., Meisel, C., and Meisel, A. (2020). Interaction of Microglia with Infiltrating Immune Cells in the Different Phases of Stroke. Brain Pathol. 30, e12911-1218. doi:10.1111/bpa.12911

Bhatia, R., Hill, M. D., Shobha, N., Menon, B., Bal, S., Kochar, P., et al. (2010). Low Rates of Acute Recanalization with Intravenous Recombinant Tissue Plasminogen Activator in Ischemic Stroke: Real-World Experience and a Call for Action. Stroke 41, 2254-2258. doi:10.1161/STROKEAHA.110.592535

Blackmore, D. G., Steyn, F. J., Carlisle, A., O’keeffe, I., Vien, K. Y., Zhou, X., et al. (2021). An Exercise "sweet Spot" Reverses Cognitive Deficits of Aging by Growth-Hormone-Induced Neurogenesis. iScience 24, 103275. doi:10.1016/j. isci.2021.103275

Caleo, M. (2015). Rehabilitation and Plasticity Following Stroke: Insights from Rodent Models. Neuroscience 311, 180-194. doi:10.1016/j.neuroscience.2015. 10.029

Casaletto, K. B., Lindbergh, C. A., Vandebunte, A., Neuhaus, J., Schneider, J. A., Buchman, A. S., et al. (2022). Microglial Correlates of Late Life Physical Activity: Relationship with Synaptic and Cognitive Aging in Older Adults. J. Neurosci. 42, 288-298. doi:10.1523/JNEUROSCI.1483-21.2021

Ceulemans, A. G., Zgavc, T., Kooijman, R., Hachimi-Idrissi, S., Sarre, S., and Michotte, Y. (2010). The Dual Role of the Neuroinflammatory Response after Ischemic Stroke: Modulatory Effects of Hypothermia. J. Neuroinflammation 7, 74. doi:10.1186/1742-2094-7-74

Chaudhry, K., Rogers, R., Guo, M., Lai, Q., Goel, G., Liebelt, B., et al. (2010). Matrix Metalloproteinase-9 (MMP-9) Expression and Extracellular SignalRegulated Kinase 1 and 2 (ERK1/2) Activation in Exercise-Reduced Neuronal Apoptosis after Stroke. Neurosci. Lett. 474, 109-114. doi:10.1016/j.neulet. 2010.03.020

Chen, J., Yang, Y., Shen, L., Ding, W., Chen, X., Wu, E., et al. (2017). Hypoxic Preconditioning Augments the Therapeutic Efficacy of Bone Marrow Stromal Cells in a Rat Ischemic Stroke Model. Cell Mol Neurobiol 37, 1115-1129. doi:10. 1007/s10571-016-0445-1

Chen, W., Jiang, L., Hu, Y., Fang, G., Yang, B., Li, J., et al. (2021). Nanomedicines, an Emerging Therapeutic Regimen for Treatment of Ischemic Cerebral Stroke: A Review. J. Control. Release 340, 342-360. doi:10.1016/j.jconrel.2021.10.020

Cheng, J., Shen, W., Jin, L., Pan, J., Zhou, Y., Pan, G., et al. (2020). Treadmill Exercise Promotes Neurogenesis and Myelin Repair via Upregulating Wnt/ $\beta$ catenin S-ignaling $\mathrm{P}$-athways in the J-uvenile B-rain F-ollowing F-ocal C-erebral I-schemia/reperfusion. Int. J. Mol. Med. 45, 1447-1463. doi:10. 3892/ijmm.2020.4515

Cheng, Y. L., Park, J. S., Manzanero, S., Choi, Y., Baik, S. H., Okun, E., et al. (2014). Evidence that Collaboration between HIF-1 $\alpha$ and Notch-1 Promotes Neuronal Cell Death in Ischemic Stroke. Neurobiol. Dis. 62, 286-295. doi:10.1016/j.nbd. 2013.10.009

Choi, J. H., Kim, T. S., Park, J. K., Sim, Y. J., Kim, K., and Lee, S. J. (2013). Shortterm Treadmill Exercise Preserves Sensory-Motor Function through Inhibiting Apoptosis in the hippocampus of Hypoxic Ischemia Injury Rat Pups. J. Exerc. Rehabil. 9, 457-462. doi:10.12965/jer.130055

Chrishtop, V. V., Tomilova, I. K., Rumyantseva, T. A., Mikhaylenko, E. V., AvilaRodriguez, M. F., Mikhaleva, L. M., et al. (2020). The Effect of Short-Term Physical Activity on the Oxidative Stress in Rats with Different Stress Resistance Profiles in Cerebral Hypoperfusion. Mol. Neurobiol. 57, 3014-3026. doi:10. 1007/s12035-020-01930-5

Codd, L. N., Blackmore, D. G., Vukovic, J., and Bartlett, P. F. (2020). Exercise Reverses Learning Deficits Induced by Hippocampal Injury by Promoting Neurogenesis. Sci. Rep. 10, 19269. doi:10.1038/s41598-020-76176-1

Correia, P. N., Meyer, I. A., Eskandari, A., Amiguet, M., Hirt, L., and Michel, P. (2021). Preconditioning by Preceding Ischemic Cerebrovascular Events. J. Am. Heart Assoc. 10, e020129. doi:10.1161/JAHA.120.020129
Curry, A., Guo, M., Patel, R., Liebelt, B., Sprague, S., Lai, Q., et al. (2010). Exercise Pre-Conditioning Reduces Brain Inflammation in Stroke via Tumor Necrosis Factor-Alpha, Extracellular Signal-Regulated Kinase $1 / 2$ and Matrix Metalloproteinase-9 Activity. Neurol. Res. 32, 756-762.

Dinuzzo, M., Giove, F., Maraviglia, B., and Mangia, S. (2017). Computational Flux Balance Analysis Predicts that Stimulation of Energy Metabolism in Astrocytes and Their Metabolic Interactions with Neurons Depend on Uptake of K+ rather Than Glutamate. Neurochem. Res. 42, 202-216. doi:10.1007/s11064-0162048-0

Diprose, W. K., Wang, M. T. M., Ghate, K., Brew, S., Caldwell, J. R., Mcguinness, B., et al. (2021). Adjunctive Intraarterial Thrombolysis in Endovascular Thrombectomy: A Systematic Review and Meta-Analysis. Neurology 10, 1212. doi:10.1212/WNL.0000000000012112

Dornbos, D., 3rd, Zwagerman, N., Guo, M., Ding, J. Y., Peng, C., Esmail, F., et al. (2013). Preischemic Exercise Reduces Brain Damage by Ameliorating Metabolic Disorder in Ischemia/reperfusion Injury. J. Neurosci. Res. 91, 818-827. doi:10.1002/jnr.23203

Du, X., Yang, J., Liu, C., Wang, S., Zhang, C., Zhao, H., et al. (2020). HypoxiaInducible Factor $1 \alpha$ and $2 \alpha$ Have Beneficial Effects in Remote Ischemic Preconditioning against Stroke by Modulating Inflammatory Responses in Aged Rats. Front. Aging Neurosci. 12, 54. doi:10.3389/fnagi.2020.00054

Duan, J., Gao, S., Tu, S., Lenahan, C., Shao, A., and Sheng, J. (2021). Pathophysiology and Therapeutic Potential of NADPH Oxidases in Ischemic Stroke-Induced Oxidative Stress. Oxid Med. Cel Longev 2021, 6631805. doi:10.1155/2021/6631805

Egan, K. J., Janssen, H., Sena, E. S., Longley, L., Speare, S., Howells, D. W., et al. (2014). Exercise Reduces Infarct Volume and Facilitates Neurobehavioral Recovery: Results from a Systematic Review and Meta-Analysis of Exercise in Experimental Models of Focal Ischemia. Neurorehabil. Neural Repair 28, 800-812. doi:10.1177/1545968314521694

Fan, Y., Wang, Y., Ji, W., Liu, K., and Wu, H. (2021). Exercise Preconditioning Ameliorates Cognitive Impairment and Anxiety-Like Behavior via Regulation of Dopamine in Ischemia Rats. Physiol. Behav. 233, 113353.

Feng, R., Zhang, M., Wang, X., Li, W.B., Ren, S.Q., and Zhang, F. (2014). PreIschemic Exercise Alleviates Oxidative Damage Following Ischemic Stroke in Rats. Exp. Ther. Med. 8, 1325-1329.

Ferrer, I., Friguls, B., Dalfó, E., Justicia, C., and Planas, A. M. (2003). Caspasedependent and Caspase-independent Signalling of Apoptosis in the Penumbra Following Middle Cerebral Artery Occlusion in the Adult Rat. Neuropathol. Appl. Neurobiol. 29, 472-481. doi:10.1046/j.1365-2990.2003.00485.x

Fleitas, J. C., Hammuod, S. F. P., Kakuta, E., and Loreti, E. H. (2022). A MetaAnalysis of the Effects of Physical Exercise on Peripheral Levels of a BrainDerived Neurotrophic Factor in the Elderly. Biomarkers 12, 1-10. doi:10.1080/ 1354750x.2021.2024602

Gao, W., Ning, Y., Peng, Y., Tang, X., Zhong, S., and Zeng, H. (2021). LncRNA NKILA Relieves Astrocyte Inflammation and Neuronal Oxidative Stress after Cerebral Ischemia/reperfusion by Inhibiting the NF-Kb Pathway. Mol. Immunol. 139, 32-41. doi:10.1016/j.molimm.2021.08.002

Gladstone, D. J., Black, S. E., and Hakim, A. M. (2002). Toward Wisdom from Failure: Lessons from Neuroprotective Stroke Trials and New Therapeutic Directions. Stroke 33, 2123-2136. doi:10.1161/01.str.0000025518.34157.51

Griffiths, H. R., Dias, I. H., Willetts, R. S., and Devitt, A. (2014). Redox Regulation of Protein Damage in Plasma. Redox Biol. 2, 430-435. doi:10.1016/j.redox.2014. 01.010

Guglielmotto, M., Aragno, M., Autelli, R., Giliberto, L., Novo, E., Colombatto, S. et al. (2009). The Up-Regulation of BACE1 Mediated by Hypoxia and Ischemic Injury: Role of Oxidative Stress and HIFlalpha. J. Neurochem. 108, 1045-1056. doi:10.1111/j.1471-4159.2008.05858.x

Hafez, S., Eid, Z., Alabasi, S., Darwiche, Y., Channaoui, S., and Hess, D. C. (2021). Mechanisms of Preconditioning Exercise-Induced Neurovascular Protection in Stroke. J. Stroke 23, 312-326. doi:10.5853/jos.2020.03006

Hafez, S., Khan, M. B., Awad, M. E., Wagner, J. D., and Hess, D. C. (2020). ShortTerm Acute Exercise Preconditioning Reduces Neurovascular Injury after Stroke through Induced eNOS Activation. Transl Stroke Res. 11, 851-860. doi:10.1007/s12975-019-00767-y

He, Q., Ma, Y., Liu, J., Zhang, D., Ren, J., Zhao, R., et al. (2021). Biological Functions and Regulatory Mechanisms of Hypoxia-Inducible Factor-1a in Ischemic Stroke. Front. Immunol. 12, 801985. doi:10.3389/fimmu.2021.801985 
He, X. F., Liu, D. X., Zhang, Q., Liang, F. Y., Dai, G. Y., Zeng, J. S., et al. (2017). Voluntary Exercise Promotes Glymphatic Clearance of Amyloid Beta and Reduces the Activation of Astrocytes and Microglia in Aged Mice. Front. Mol. Neurosci. 10, 144. doi:10.3389/fnmol.2017.00144

Hong, M., Kim, M., Kim, T. W., Park, S. S., Kim, M. K., Park, Y. H., et al. (2020). Treadmill Exercise Improves Motor Function and Short-Term Memory by Enhancing Synaptic Plasticity and Neurogenesis in Photothrombotic Stroke Mice. Int. Neurourol J. 24, S28-S38. doi:10.5213/inj.2040158.079

Hou, K., Li, G., Yu, J., Xu, K., and Wu, W. (2021). Receptors, Channel Proteins, and Enzymes Involved in Microglia-Mediated Neuroinflammation and Treatments by Targeting Microglia in Ischemic Stroke. Neuroscience 460, 167-180. doi:10. 1016/j.neuroscience.2021.02.018

Hsieh, F. I., Lien, L. M., Chen, S. T., Bai, C. H., Sun, M. C., Tseng, H. P., et al. (2010). Get with the Guidelines-Stroke Performance Indicators: Surveillance of Stroke Care in the Taiwan Stroke Registry: Get with the Guidelines-Stroke in Taiwan. Circulation 122, 1116-1123. doi:10.1161/CIRCULATIONAHA.110.936526

Jelinek, M., Jurajda, M., and Duris, K. (2021). Oxidative Stress in the Brain: Basic Concepts and Treatment Strategies in Stroke. Antioxidants (Basel) 10, 1886. doi:10.3390/antiox10121886

Jensen, C. J., Massie, A., and De Keyser, J. (2013). Immune Players in the CNS: the Astrocyte. J. Neuroimmune Pharmacol. 8, 824-839. doi:10.1007/s11481-0139480-6

Jiang, Q., Geng, X., Warren, J., Eugene Paul Cosky, E., Kaura, S., Stone, C., et al. (2020). Hypoxia Inducible Factor-1 $\alpha$ (HIF-1 $\alpha$ ) Mediates NLRP3 Inflammasome-Dependent-Pyroptotic and Apoptotic Cell Death Following Ischemic Stroke. Neuroscience 448, 126-139. doi:10.1016/j.neuroscience. 2020.09.036

Jiang, T., Luo, J., Pan, X., Zheng, H., Yang, H., Zhang, L., et al. (2021). Physical Exercise Modulates the Astrocytes Polarization, Promotes Myelin Debris Clearance and Remyelination in Chronic Cerebral Hypoperfusion Rats. Life Sci. 278, 119526. doi:10.1016/j.lfs.2021.119526

Jones, T. A. (2017). Motor Compensation and its Effects on Neural Reorganization after Stroke. Nat. Rev. Neurosci. 18, 267-280. doi:10.1038/nrn.2017.26

Kalyanaraman, B. (2013). Teaching the Basics of Redox Biology to Medical and Graduate Students: Oxidants, Antioxidants and Disease Mechanisms. Redox Biol. 1, 244-257. doi:10.1016/j.redox.2013.01.014

Kang, R., Gamdzyk, M., Lenahan, C., Tang, J., Tan, S., and Zhang, J. H. (2020). The Dual Role of Microglia in Blood-Brain Barrier Dysfunction after Stroke. Curr. Neuropharmacol 18, 1237-1249. doi:10.2174/1570159X18666200529150907

Kaur, M. M., and Sharma, D. S. (2022). Mitochondrial Repair as Potential Pharmacological Target in Cerebral Ischemia. Mitochondrion 63, 23-31. doi:10.1016/j.mito.2022.01.001

Kieran, N. W., Suresh, R., Dorion, M.-F., Macdonald, A., Blain, M., Wen, D., et al. (2022). MicroRNA-210 Regulates the Metabolic and Inflammatory Status of Primary Human Astrocytes. J. Neuroinflammation 19, 10. doi:10.1186/s12974021-02373-y

Kim, S. E., Ko, I. G., Kim, B. K., Shin, M. S., Cho, S., Kim, C. J., et al. (2010). Treadmill Exercise Prevents Aging-Induced Failure of Memory through an Increase in Neurogenesis and Suppression of Apoptosis in Rat hippocampus. Exp. Gerontol. 45, 357-365. doi:10.1016/j.exger.2010.02.005

Lee, J. M., Baek, S. S., Kim, T. W., Park, H. S., Park, S. S., Park, J. M., et al. (2019). Preischemic Treadmill Exercise Improves Short-Term Memory by Inhibiting Hypoperfusion-Induced Disruption of Blood-Brain Barrier after Bilateral Common Carotid Arteries Occlusion. J. Exerc. Rehabil. 15, 370-376. doi:10. 12965/jer.1938274.137

Leite, H. R., Mourão, F. A., Drumond, L. E., Ferreira-Vieira, T. H., Bernardes, D., Silva, J. F., et al. (2012). Swim Training Attenuates Oxidative Damage and Promotes Neuroprotection in Cerebral Cortical Slices Submitted to Oxygen Glucose Deprivation. J. Neurochem. 123, 317-324. doi:10.1111/j.1471-4159. 2012.07898.x

Li, C., Zhang, B., Zhu, Y., Li, Y., Liu, P., Gao, B., et al. (2017a). Post-stroke Constraint-Induced Movement Therapy Increases Functional Recovery, Angiogenesis, and Neurogenesis with Enhanced Expression of HIF-1a and VEGF. Curr. Neurovasc Res. 14, 368-377. doi:10.2174/ 1567202614666171128120558

Li, F., Geng, X., Huber, C., Stone, C., and Ding, Y. (2020a). In Search of a Dose: The Functional and Molecular Effects of Exercise on Post-stroke Rehabilitation in Rats. Front Cel Neurosci 14, 186. doi:10.3389/fncel.2020.00186
Li, F., Geng, X., Lee, H., Wills, M., and Ding, Y. (2021a). Neuroprotective Effects of Exercise Postconditioning after Stroke via SIRT1-Mediated Suppression of Endoplasmic Reticulum (ER) Stress. Front. Cel Neurosci 15, 598230. doi:10. 3389/fncel.2021.598230

Li, F., Shi, W., Zhao, E. Y., Geng, X., Li, X., Peng, C., et al. (2017b). Enhanced Apoptosis from Early Physical Exercise Rehabilitation Following Ischemic Stroke. J. Neurosci. Res. 95, 1017-1024. doi:10.1002/jnr.23890

Li, P., Stetler, R. A., Leak, R. K., Shi, Y., Li, Y., Yu, W., et al. (2018). Oxidative Stress and DNA Damage after Cerebral Ischemia: Potential Therapeutic Targets to Repair the Genome and Improve Stroke Recovery. Neuropharmacology 134, 208-217. doi:10.1016/j.neuropharm.2017.11.011

Li, Y., Zheng, J., Zhu, Y., Qu, Y., Suo, R., and Zhu, Y. (2021b). Neuroprotective Effects of Methylcobalamin in Cerebral Ischemia/reperfusion Injury through Activation of the ERK1/2 Signaling Pathway. Int. Immunopharmacol 99, 108040. doi:10.1016/j.intimp.2021.108040

Li, Z., Meng, X., Ren, M., and Shao, M. (2020b). Combination of Scalp Acupuncture with Exercise Therapy Effectively Counteracts Ischemic Brain Injury in Rats. J. Stroke Cerebrovasc. Dis. 29, 105286. doi:10.1016/j. jstrokecerebrovasdis.2020.105286

Liebelt, B., Papapetrou, P., Ali, A., Guo, M., Ji, X., Peng, C., et al. (2010). Exercise Preconditioning Reduces Neuronal Apoptosis in Stroke by Up-Regulating Heat Shock Protein-70 (Heat Shock Protein-72) and Extracellular-Signal-RegulatedKinase 1/2. Neuroscience 166, 1091-1100. doi:10.1016/j.neuroscience.2009. 12.067

Lin, C. M., Chang, C. K., Chang, C. P., Hsu, Y. C., Lin, M. T., and Lin, J. W. (2015). Protecting against Ischaemic Stroke in Rats by Heat Shock Protein 20-mediated Exercise. Eur. J. Clin. Invest. 45, 1297-1305. doi:10.1111/eci.12551

Liu, J., Gu, Y., Guo, M., and Ji, X. (2021a). Neuroprotective Effects and Mechanisms of Ischemic/hypoxic Preconditioning on Neurological Diseases. CNS Neurosci. Ther. 27, 869-882. doi:10.1111/cns.13642

Liu, J., Narasimhan, P., Yu, F., and Chan, P. H. (2005). Neuroprotection by Hypoxic Preconditioning Involves Oxidative Stress-Mediated Expression of Hypoxia-Inducible Factor and Erythropoietin. Stroke 36, 1264-1269. doi:10. 1161/01.STR.0000166180.91042.02

Liu, M. X., Luo, L., Fu, J. H., He, J. Y., Chen, M. Y., He, Z. J., et al. (2022b). Exerciseinduced Neuroprotection against Cerebral Ischemia/reperfusion Injury Is Mediated via Alleviating Inflammasome-Induced Pyroptosis. Exp. Neurol. 349, 113952. doi:10.1016/j.expneurol.2021.113952

Liu, P. K. (2003). Ischemia-reperfusion-related Repair Deficit after Oxidative Stress: Implications of Faulty Transcripts in Neuronal Sensitivity after Brain Injury. J. Biomed. Sci. 10, 4-13. doi:10.1007/BF02255992

Liu, P. K., Robertson, C. S., and Valadka, A. (2002). The Association between Neuronal Nitric Oxide Synthase and Neuronal Sensitivity in the Brain after Brain Injury. Ann. N. Y Acad. Sci. 962, 226-241. doi:10.1111/j.1749-6632.2002. tb04071.x

Liu, Y. J., Cui, Z. Y., Yang, A. L., Jallow, A. W., Huang, H. L., Shan, C. L., et al. (2021d). Anti-apoptotic and Pro-survival Effect of Exercise Training on Early Aged Hypertensive Rat Cerebral Cortex. Aging (Albany NY) 13, 20495-20510. doi:10.18632/aging.203431

Liu, Y., Yang, J., Che, X., Huang, J., Zhang, X., Fu, X., et al. (2021c). Agonistic Analog of Growth Hormone-Releasing Hormone Promotes Neurofunctional Recovery and Neural Regeneration in Ischemic Stroke. Proc. Natl. Acad. Sci. US A. 118, e2109600118. doi:10.1073/pnas.2109600118

Lu, J., Wang, J., Yu, L., Cui, R., Zhang, Y., Ding, H., et al. (2021). Treadmill Exercise Attenuates Cerebral Ischemia-Reperfusion Injury by Promoting Activation of M2 Microglia via Upregulation of Interleukin-4. Front. Cardiovasc. Med. 8, 735485. doi:10.3389/fcvm.2021.735485

Lushchak, V. I., Duszenko, M., Gospodaryov, D. V., and Garaschuk, O. (2021). Oxidative Stress and Energy Metabolism in the Brain: Midlife as a Turning Point. Antioxidants (Basel) 10, 1715. doi:10.3390/antiox10111715

Ma, Y., Yang, S., He, Q., Zhang, D., and Chang, J. (2021). The Role of Immune Cells in Post-Stroke Angiogenesis and Neuronal Remodeling: The Known and the Unknown. Front. Immunol. 12, 784098. doi:10.3389/fimmu.2021.784098

Mi, J., Yang, Y., Yao, H., Huan, Z., Xu, C., Ren, Z., et al. (2021). Inhibition of Heat Shock Protein Family A Member 8 Attenuates Spinal Cord IschemiaReperfusion Injury via Astrocyte NF-Kb/nlrp3 Inflammasome Pathway : HSPA8 Inhibition Protects Spinal Ischemia-Reperfusion Injury. J. Neuroinflammation 18, 170. doi:10.1186/s12974-021-02220-0 
Mitsios, N., Gaffney, J., Krupinski, J., Mathias, R., Wang, Q., Hayward, S., et al. (2007). Expression of Signaling Molecules Associated with Apoptosis in Human Ischemic Stroke Tissue. Cell Biochem Biophys 47, 73-86. doi:10. 1385/cbb:47:1:73

Miyata, T., Takizawa, S., and Van Ypersele De Strihou, C. (2011). Hypoxia. 1. Intracellular Sensors for Oxygen and Oxidative Stress: Novel Therapeutic Targets. Am. J. Physiol. Cel Physiol 300, C226-C231. doi:10.1152/ajpcell. 00430.2010

Moldogazieva, N. T., Mokhosoev, I. M., Feldman, N. B., and Lutsenko, S. V. (2018). ROS and RNS Signalling: Adaptive Redox Switches through Oxidative/ nitrosative Protein Modifications. Free Radic. Res. 52, 507-543. doi:10.1080/ 10715762.2018.1457217

Moujalled, D., Strasser, A., and Liddell, J. R. (2021). Molecular Mechanisms of Cell Death in Neurological Diseases. Cell Death Differ 28, 2029-2044. doi:10.1038/ s41418-021-00814-y

Naderi, S., Alimohammadi, R., Hakimizadeh, E., Roohbakhsh, A., Shamsizadeh, A., and Allahtavakoli, M. (2018). The Effect of Exercise Preconditioning on Stroke Outcome in Ovariectomized Mice with Permanent Middle Cerebral Artery Occlusion. Can. J. Physiol. Pharmacol. 96, 287-294. doi:10.1139/cjpp-20170157

Otsuka, S., Sakakima, H., Sumizono, M., Takada, S., Terashi, T., and Yoshida, Y. (2016). The Neuroprotective Effects of Preconditioning Exercise on Brain Damage and Neurotrophic Factors after Focal Brain Ischemia in Rats. Behav. Brain Res. 303, 9-18. doi:10.1016/j.bbr.2016.01.049

Otsuka, S., Sakakima, H., Tani, A., Nakanishi, K., Takada, S., Norimatsu, K., et al. (2021a). Effects of Detraining on Preconditioning Exercise-Induced Neuroprotective Potential after Ischemic Stroke in Rats. Brain Struct. Funct. 226, 2169-2180. doi:10.1007/s00429-021-02317-5

Otsuka, S., Sakakima, H., Terashi, T., Takada, S., Nakanishi, K., and Kikuchi, K. (2019). Preconditioning Exercise Reduces Brain Damage and Neuronal Apoptosis through Enhanced Endogenous 14-3-3 $\gamma$ after Focal Brain Ischemia in Rats. Brain Struct. Funct. 224, 727-738. doi:10.1007/s00429018-1800-4

Otsuka, S., Setoyama, K., Takada, S., Nakanishi, K., Terashi, T., Norimatsu, K., et al. (2021b). Preconditioning Exercise in Rats Attenuates Early Brain Injury Resulting from Subarachnoid Hemorrhage by Reducing Oxidative Stress, Inflammation, and Neuronal Apoptosis. Mol. Neurobiol. 58, 5602-5617. doi:10.1007/s12035-021-02506-7

Park, M. Y., Ha, S. E., Vetrivel, P., Kim, H. H., Bhosale, P. B., Abusaliya, A., et al. (2021a). Differences of Key Proteins between Apoptosis and Necroptosis. Biomed. Res. Int. 2021, 3420168. doi:10.1155/2021/3420168

Park, S. S., Kim, T. W., Sung, Y. H., Park, Y. J., Kim, M. K., and Shin, M. S. (2021b). Treadmill Exercise Ameliorates Short-Term Memory Impairment by Suppressing Hippocampal Neuroinflammation in Poloxamer-407-Induced Hyperlipidemia Rats. Int. Neurourol J. 25, S81-S89. doi:10.5213/inj. 2142342.171

Peng, X., Li, C., Yu, W., Liu, S., Cong, Y., Fan, G., et al. (2020). Propofol Attenuates Hypoxia-Induced Inflammation in BV2 Microglia by Inhibiting Oxidative Stress and NF-кB/Hif-1a Signaling. Biomed. Res. Int. 2020, 8978704. doi:10. $1155 / 2020 / 8978704$

Pluta, R., Januszewski, S., and Czuczwar, S. J. (2021). Neuroinflammation in PostIschemic Neurodegeneration of the Brain: Friend, Foe, or Both? Int. J. Mol. Sci. 22. 4405, doi:10.3390/ijms 22094405

Prentice, H., Modi, J. P., and Wu, J. Y. (2015). Mechanisms of Neuronal Protection against Excitotoxicity, Endoplasmic Reticulum Stress, and Mitochondrial Dysfunction in Stroke and Neurodegenerative Diseases. Oxid Med. Cel Longev 2015, 964518. doi:10.1155/2015/964518

Puderbaugh, M., and Emmady, P. D. (2022). Neuroplasticity. StatPearls Publishing.

Radak, D., Katsiki, N., Resanovic, I., Jovanovic, A., Sudar-Milovanovic, E., Zafirovic, S., et al. (2017). Apoptosis and Acute Brain Ischemia in Ischemic Stroke. Curr. Vasc. Pharmacol. 15, 115-122. doi:10.2174/ 1570161115666161104095522

Radak, Z., Kumagai, S., Taylor, A. W., Naito, H., and Goto, S. (2007). Effects of Exercise on Brain Function: Role of Free Radicals. Appl. Physiol. Nutr. Metab. 32, 942-946. doi:10.1139/H07-081

Redza-Dutordoir, M., and Averill-Bates, D. A. (2016). Activation of Apoptosis Signalling Pathways by Reactive Oxygen Species. Biochim. Biophys. Acta 1863, 2977-2992. doi:10.1016/j.bbamcr.2016.09.012
Regunathan, S., and Piletz, J. E. (2003). Regulation of Inducible Nitric Oxide Synthase and Agmatine Synthesis in Macrophages and Astrocytes. Ann. N. Y Acad. Sci. 1009, 20-29. doi:10.1196/annals.1304.002

Rezaei, R., Nasoohi, S., Haghparast, A., Khodagholi, F., Bigdeli, M.R., and Nourshahi, M. (2018). High Intensity Exercise Preconditioning Provides Differential Protection Against Brain Injury Following Experimental Stroke. Life Sci. 207, 30-35.

Ripley, A. J., Jeffers, M. S., Mcdonald, M. W., Montroy, J., Dykes, A., Fergusson, D. A., et al. (2021). Neuroprotection by Remote Ischemic Conditioning in Rodent Models of Focal Ischemia: a Systematic Review and Meta-Analysis. Transl Stroke Res. 12, 461-473. doi:10.1007/s12975-020-00882-1

Sakakima, H. (2019). Endogenous Neuroprotective Potential Due to Preconditioning Exercise in Stroke. Phys. Ther. Res. 22, 45-52. doi:10.1298/ ptr.R0006

Saleem, S. (2021). Apoptosis, Autophagy, Necrosis and Their Multi Galore Crosstalk in Neurodegeneration. Neuroscience 469, 162-174. doi:10.1016/j. neuroscience.2021.06.023

Sancho, L., Contreras, M., and Allen, N. J. (2021). Glia as Sculptors of Synaptic Plasticity. Neurosci. Res. 167, 17-29. doi:10.1016/j.neures.2020.11.005

Schimidt, H. L., Vieira, A., Altermann, C., Martins, A., Sosa, P., Santos, F. W., et al. (2014). Memory Deficits and Oxidative Stress in Cerebral IschemiaReperfusion: Neuroprotective Role of Physical Exercise and green tea Supplementation. Neurobiol. Learn. Mem. 114, 242-250. doi:10.1016/j.nlm. 2014.07.005

Schönfeld, P., and Reiser, G. (2017). Brain Energy Metabolism Spurns Fatty Acids as Fuel Due to Their Inherent Mitotoxicity and Potential Capacity to Unleash Neurodegeneration. Neurochem. Int. 109, 68-77. doi:10.1016/j.neuint.2017. 03.018

Shamsaei, N., Khaksari, M., Erfani, S., Rajabi, H., and Aboutaleb, N. (2015). Exercise Preconditioning Exhibits Neuroprotective Effects on Hippocampal CA1 Neuronal Damage after Cerebral Ischemia. Neural Regen. Res. 10, 1245-1250. doi:10.4103/1673-5374.162756

Shao, A., Lin, D., Wang, L., Tu, S., Lenahan, C., and Zhang, J. (2020). Oxidative Stress at the Crossroads of Aging, Stroke and Depression. Aging Dis. 11, 1537-1566. doi:10.14336/AD.2020.0225

Soejima, Y., Hu, Q., Krafft, P. R., Fujii, M., Tang, J., and Zhang, J. H. (2013). Hyperbaric Oxygen Preconditioning Attenuates Hyperglycemia-Enhanced Hemorrhagic Transformation by Inhibiting Matrix Metalloproteinases in Focal Cerebral Ischemia in Rats. Exp. Neurol. 247, 737-743. doi:10.1016/j. expneurol.2013.03.019

Sosa, P. M., Schimidt, H. L., Altermann, C., Vieira, A. S., Cibin, F. W., Carpes, F. P., et al. (2015). Physical Exercise Prevents Motor Disorders and Striatal Oxidative Imbalance after Cerebral Ischemia-Reperfusion. Braz. J. Med. Biol. Res. 48, 798-804. doi:10.1590/1414-431X20154429

Subedi, L., and Gaire, B. P. (2021a). Neuroprotective Effects of Curcumin in Cerebral Ischemia: Cellular and Molecular Mechanisms. ACS Chem. Neurosci. 12, 2562-2572. doi:10.1021/acschemneuro.1c00153

Subedi, L., and Gaire, B. P. (2021b). Phytochemicals as Regulators of Microglia/ macrophages Activation in Cerebral Ischemia. Pharmacol. Res. 165, 105419. doi:10.1016/j.phrs.2021.105419

Sun, L. N., Qi, J. S., and Gao, R. (2018). Physical Exercise Reserved Amyloid-Beta Induced Brain Dysfunctions by Regulating Hippocampal Neurogenesis and Inflammatory Response via MAPK Signaling. Brain Res. 1697, 1-9. doi:10. 1016/j.brainres.2018.04.040

Svensson, M., Rosvall, P., Boza-Serrano, A., Andersson, E., Lexell, J., and Deierborg, T. (2016). Forced Treadmill Exercise can Induce Stress And Increase Neuronal Damage in a Mouse Model of Global Cerebral Ischemia. Neurobiol. Stress 5, 8-18.

Tahamtan, M., Allahtavakoli, M., Abbasnejad, M., Roohbakhsh, A., Taghipour, Z., Taghavi, M., et al. (2013). Exercise Preconditioning Improves Behavioral Functions Following Transient Cerebral Ischemia Induced by 4-vessel Occlusion (4-VO) in Rats. Arch. Iran Med. 16, 697-704. doi:10.131612/ AIM.004

Teymuri Kheravi, M., Nayebifar, S., Aletaha, S. M., and Sarhadi, S. (2021). The Effect of Two Types of Exercise Preconditioning on the Expression of TrkB, TNF- $\alpha$, and MMP2 Genes in Rats with Stroke. Biomed. Res. Int. 2021, 5595368.

Terashi, T., Otsuka, S., Takada, S., Nakanishi, K., Ueda, K., Sumizono, M., et al. (2019). Neuroprotective Effects of Different Frequency Preconditioning 
Exercise on Neuronal Apoptosis after Focal Brain Ischemia in Rats. Neurol. Res. 41, 510-518. doi:10.1080/01616412.2019.1580458

Uzdensky, A. B. (2019). Apoptosis Regulation in the Penumbra after Ischemic Stroke: Expression of Pro- and Antiapoptotic Proteins. Apoptosis 24, 687-702. doi:10.1007/s10495-019-01556-6

Van Praag, H., Shubert, T., Zhao, C., and Gage, F. H. (2005). Exercise Enhances Learning and Hippocampal Neurogenesis in Aged Mice. J. Neurosci. 25, 8680-8685. doi:10.1523/JNEUROSCI.1731-05.2005

Wahlgren, N. G., and Ahmed, N. (2004). Neuroprotection in Cerebral Ischaemia: Facts and Fancies-Tthe Need for New Approaches. Cerebrovasc. Dis. 17 Suppl 1 (Suppl. 1), 153-166. doi:10.1159/000074808

Wang, J., Liu, H., Chen, S., Zhang, W., Chen, Y., and Yang, Y. (2020). Moderate Exercise Has Beneficial Effects on Mouse Ischemic Stroke by Enhancing the Functions of Circulating Endothelial Progenitor Cell-Derived Exosomes. Exp. Neurol. 330, 113325. doi:10.1016/j.expneurol.2020.113325

Wang, L., Deng, W., Yuan, Q., and Yang, H. (2015). Exercise Preconditioning Reduces Ischemia Reperfusion-Induced Focal Cerebral Infarct Volume Through Up-Regulating the Expression of HIF-1a. Pak. J. Pharm. Sci. 28, 791-798.

Wang, X., Zhang, M., Yang, S. D., Li, W. B., Ren, S. Q., Zhang, J., and Zhang, F. (2014). Pre-Ischemic Treadmill Training Alleviates Brain Damage via GLT-1-Mediated Signal Pathway After Ischemic Stroke In Rats. Neuroscience 274, 393-402.

Wang, Y., Zhang, J. H., Sheng, J., and Shao, A. (2019a). Immunoreactive Cells after Cerebral Ischemia. Front. Immunol. 10, 2781. doi:10.3389/fimmu.2019.02781

Wang, Y. L., Lin, C. H., Chen, C. C., Chang, C. P., Lin, K. C., Su, F. C., et al. (2019b). Exercise Preconditioning Attenuates Neurological Injury by Preserving Old and Newly Formed HSP72-Containing Neurons in Focal Brain Ischemia Rats. Int. J. Med. Sci. 16, 675-685. doi:10.7150/ijms.32962

Wei, Q., Deng, H., Cui, H., Fang, J., Zuo, Z., Deng, J., et al. (2018). A Mini Review of Fluoride-Induced Apoptotic Pathways. Environ. Sci. Pollut. Res. Int. 25, 33926-33935. doi:10.1007/s11356-018-3406-Z

Xu, L., Zhu, L., Zhu, L., Chen, D., Cai, K., Liu, Z., et al. (2021). Moderate Exercise Combined with Enriched Environment Enhances Learning and Memory through BDNF/TrkB Signaling Pathway in Rats. Int. J. Environ. Res. Public Health 18, 8283. doi:10.3390/ijerph18168283

Xu, S., Lu, J., Shao, A., Zhang, J. H., and Zhang, J. (2020). Glial Cells: Role of the Immune Response in Ischemic Stroke. Front. Immunol. 11, 294. doi:10.3389/ fimmu.2020.00294

Yang, B., Wang, L., Nie, Y., Wei, W., and Xiong, W. (2021a). proBDNF Expression Induces Apoptosis and Inhibits Synaptic Regeneration by Regulating the RhoAJNK Pathway in an In Vitro post-stroke Depression Model. Transl Psychiatry 11, 578. doi:10.1038/s41398-021-01667-2

Yang, J., Liu, C., Du, X., Liu, M., Ji, X., Du, H., et al. (2018). Hypoxia Inducible Factor 1a Plays a Key Role in Remote Ischemic Preconditioning against Stroke by Modulating Inflammatory Responses in Rats. J. Am. Heart Assoc. 7, e007589. doi:10.1161/JAHA.117.007589

Yang, T. T., Qian, F., Liu, L., Peng, X. C., Huang, J. R., Ren, B. X., et al. (2021b). Astroglial Connexins in Epileptogenesis. Seizure 84, 122-128. doi:10.1016/j. seizure.2020.11.022

Zhang, C., Zhen, L., Fang, Z., Yu, L., Zhang, Y., Wei, H., et al. (2021a). Adiponectin Treatment Attenuates Cerebral Ischemia-Reperfusion Injury through HIF-1 $\alpha$ Mediated Antioxidation in Mice. Oxid Med. Cel Longev 2021, 5531048. doi:10. $1155 / 2021 / 5531048$
Zhang, F., Wu, Y., and Jia, J. (2011). Exercise Preconditioning and Brain Ischemic Tolerance. Neuroscience 177, 170-176. doi:10.1016/j. neuroscience.2011.01.018

Zhang, L., Hu, X., Luo, J., Li, L., Chen, X., Huang, R., et al. (2013). Physical Exercise Improves Functional Recovery through Mitigation of Autophagy, Attenuation of Apoptosis and Enhancement of Neurogenesis after MCAO in Rats. BMC Neurosci. 14, 46. doi:10.1186/1471-2202-14-46

Zhang, P., Yang, L., Li, G., Jin, Y., Wu, D., Wang, Q. M., et al. (2020). Agrin Involvement in Synaptogenesis Induced by Exercise in a Rat Model of Experimental Stroke. Neurorehabil. Neural Repair 34, 1124-1137. doi:10. $1177 / 1545968320969939$

Zhang, S. (2019). Microglial Activation after Ischaemic Stroke. Stroke Vasc. Neurol. 4, 71-74. doi:10.1136/svn-2018-000196

Zhang, S. R., Phan, T. G., and Sobey, C. G. (2021b). Targeting the Immune System for Ischemic Stroke. Trends Pharmacol. Sci. 42, 96-105. doi:10.1016/j.tips.2020. 11.010

Zhang, Z., Li, R., Zhang, X., Wei, Y., Ma, H., and Zhu, L. (2019). Voluntary Exercise Promotes Neurotrophic Factor and Suppresses Apoptosis in Hippocampal Ischemia. J. Integr. Neurosci. 18, 65-70. doi:10.31083/j.jin.2019.01.118

Zheng, X., Haupt, M., Bähr, M., Tatenhorst, L., and Doeppner, T. R. (2021). Treating Cerebral Ischemia: Novel Therapeutic Strategies from Experimental Stroke Research. Chapter 11, doi:10.36255/exonpublications.cerebralischemia. 2021.therapy

Zhou, X. A., Blackmore, D. G., Zhuo, J., Nasrallah, F. A., To, X., Kurniawan, N. D., et al. (2021). Neurogenic-dependent Changes in Hippocampal Circuitry Underlie the Procognitive Effect of Exercise in Aging Mice. iScience 24, 103450. doi:10.1016/j.isci.2021.103450

Zhu, L., Ye, T., Tang, Q., Wang, Y., Wu, X., Li, H., et al. (2016) Exercise Preconditioning Regulates the Toll-Like Receptor 4/Nuclear Factor-kB Signaling Pathway and Reduces Cerebral Ischemia/Reperfusion Inflammatory Injury: A Study in Rats. J. Stroke Cerebrovasc. Dis. 25, 2770-2779.

Zong, W., Gouda, M., Cai, E., Wang, R., Xu, W., Wu, Y., et al. (2021). The Antioxidant Phytochemical Schisandrin A Promotes Neural Cell Proliferation and Differentiation after Ischemic Brain Injury. Molecules 26. 7466, doi:10. 3390/molecules 26247466

Conflict of Interest: The authors declare that the research was conducted in the absence of any commercial or financial relationships that could be construed as a potential conflict of interest.

Publisher's Note: All claims expressed in this article are solely those of the authors and do not necessarily represent those of their affiliated organizations, or those of the publisher, the editors and the reviewers. Any product that may be evaluated in this article, or claim that may be made by its manufacturer, is not guaranteed or endorsed by the publisher.

Copyright $\odot 2022 \mathrm{Zhu}$, Sun, Hu and Pan. This is an open-access article distributed under the terms of the Creative Commons Attribution License (CC BY). The use, distribution or reproduction in other forums is permitted, provided the original author(s) and the copyright owner(s) are credited and that the original publication in this journal is cited, in accordance with accepted academic practice. No use, distribution or reproduction is permitted which does not comply with these terms. 